\title{
PRODUCTIVE PERFORMANCE OF GROWING NEW ZEALAND RABBITS FED JATROPHA CURCAS SEED MEAL
}

\author{
K. M. Abd El-Rahman ${ }^{(1)}$, H.T. Taie ${ }^{(1)}$, G. A. Baraghit ${ }^{(1)}$, A.M. Soliman ${ }^{(2)}$ \\ and Shereen A.I. Rabie ${ }^{(1)}$ \\ (1) Department of Animal Production, Faculty of Agriculture, University of Menoufia, \\ Egypt.

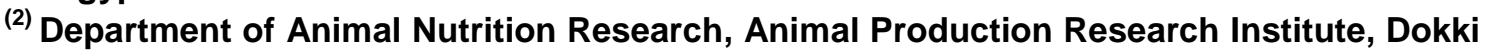 \\ - Giza, Egypt. \\ Received: Jun. 9, 2019
}

Accepted: Jun. 15, 2019

ABSTRACT: A total number of forty eight New Zealand White (NZW) rabbits 4 weeks of age and $683 \pm 28 \mathrm{~g}$ average live body weight were allotted at random to three similar experimental groups (of 16 rabbits each). Each group of rabbits was fed one of three experimental pelleted diets (16\% crude protein and $13 \%$ crude fiber on average). The feeding trail extended for 9 weeks. The aim of the study was to investigate the effects of partial substitution (50 or 100\%) of soybean meal of control diet with different levels of jatropha seed meal (JCSM) as the sources for plant protein. on growth performance, nutrients digestibility, feed conversion ratio and economic efficiency. Results indicated that, there was no differences in the feed intake of rabbits that received diets containing JCSM and those received the control diet. Replacement of JCSM in rabbit diets significantly $(P<0.05)$ improved the DM digestibility of diets containing 50 and 100\% JCSM by 6.1 and $7.7 \%$ compared with control diet. No significant differences among the experimental groups regarding DCP and TDN.

The average live body weight and body weight gain after 9 weeks showed no significant differences. The average daily gain followed the same pattern of total gain with average value of 26.89, 27.56 and $25.71 \mathrm{~g} / \mathrm{d}$. Rabbits fed control diet had feed conversion ratio of 3.00 while those fed 50 and $100 \%$ JCSM had feed conversion ratio of 3.33 and 3.28 , respectively. Nitrogen balance was positive in all rabbits fed experimental diets. Economic impact values of rabbits fed diets contained JCSM at marketing age (13 weeks) were higher than those of the control diet.

It could be concluded that substitution of jatropha seed meal up to 50 or $100 \%$ of soybean meal in the diet of growing NZW rabbit diets improved the digestibility, daily weight gain, feed and economic impact, without any adverse effects on productive performance.

Key words: Jatropha seed meal, Growth Performance, Digestibility, Nitrogen balance, New Zealand Rabbits.

\section{INTRODUCTION}

In Egypt, there is a shortage in animal protein. Rabbits could participate in solving this problem, but feed cost of rabbit meat production is still expensive due to the high prices of soybeans meal and yellow corn grains and imported hard currency. In recent years, jatropha has been introduced into Egypt as shrubs for the production of biofuels.
The planted area with J. curcas was about 700 ha in 2007 on treated wastewater in Luxor (MSEA, 2008). At present, the selling price of seed meal which is approximately $25 \%$ that of the groundnut or soy meal, on protein equivalent basis.

Under the prevailing situations, it is evident that development of a low-cost 
detoxification process, and use of the detoxified Jatropha seed meal which could be used as new sources of feedstuff with low price and high quality proteins to solve feed shortage and produce least cost diets for rabbits. If the plans for cultivation of Jatropha in different countries are realized, Jatropha seed meal, after detoxification, has a high potential to be a competitor of the soybean meal in the international feed ingredient markets (Nabil et al., 2011). Chemical composition of Jatropha seed cake is DM $95.07 \%$, CP $47.97 \%$, EE 2.66 , CF 6.98, ash 5.85 and ME $319 \mathrm{Kcal} / \mathrm{kg}$ (Agboola and Adenuga, 2015). Also, JSM had the highest arginine content, followed by aromatic (phenylalanine + tyrosine) and nonpolar amino acids; AA (leucine, isoleucine, alanine, glycine, valine, and proline) (Makkar et al., 2008, Peralta-Flores et al., 2012).

Jatropha seed meal may be used to replace the imported SBM and in the main time reduces the cost of rabbits feeding.

The study reported here in was undertaken to investigate the effect of partial replacement of JCSM instated of soybean meal on growth performance, digestibility and productive performance in growing New Zealand White (NZW) rabbits.

\section{MATERIALS AND METHODS}

\section{Animals and experimental design}

The present study was conducted on Animal Production Department, Faculty of Agriculture, Menoufia University Experimental station and laboratory of Animal Nutrition Research Department, Animal Production Research Institute, Agriculture Research and Egypt.

Forty eight growing NZW rabbits of 4 weeks old and $683 \pm 28 \mathrm{~g}$ average body weight, were distributed randomly and equally into three treatments groups, each of 16 animals. Each group was subdivided into four replicates with four animals each. Rabbits were housed in wire floor batteries of $60 \times 55 \times 40 \mathrm{~cm}$. All batteries were located in a naturally ventilated windowed house. All animals were kept under similar hygienic conditions. Rabbits were offered diets for duration of the feeding trial until reaching 13 weeks of age.

\section{Experimental diets}

The chemical composition of igrediants and diets used in the information are showed in Table (1). Three pelleted diets were prepared using JSM, as a partial substitution of 50 or $100 \%$ soybean meal (SBM) of the control diet. Feed diets were nearly iso-nitrogenous and iso-caloric and, also to the crude fiber percentages of the experimental diets nearly the same. All diets were formulated according to NRC of rabbits (1977). Table 2 show the formulation and chemical analysis of the experimental diets.

Each group of rabbits was fed one of the three experimental diets. Fresh water was automatically available at all times through stainless steel nipples for each cage. The experimental diets were offered to rabbits ad libitum. The rations were adjusted every week according to the average daily feed intake. Individual live body weight and feed intake were weekly recorded up to 13 weeks of age. Feed conversion ratio was calculated as $\mathrm{g}$ feed $/ \mathrm{g}$ gain and as $\mathrm{g}$ TDN/g gain.

Performance index (PI\%) was calculated according to North (1981) as below: PI = Live body weight $(\mathrm{kg})$ × 100 / Feed conversion. The economical efficiency was calculated by the following equation: $Y=$ [(A - B) / B], where A is selling cost of obtained gain and $B$ is the feeding cost for this gain (Cited from El-Kerdawy, 1997). 
Table 1: Chemical composition of the ingredients and diets used in formulation of the experiment diets

\begin{tabular}{|l|c|c|c|c|c|c|c|}
\hline \multirow{2}{*}{ Feed stuff } & \multirow{2}{*}{ DM } & \multicolumn{7}{|c|}{-------- On DM basis--------- } \\
\cline { 3 - 8 } & & OM & CP & EE & CF & NFE & Ash \\
\hline Alfalfa hay & 92.00 & 91.50 & 17.50 & 2.50 & 24.10 & 47.4 & 8.50 \\
\hline Yellow corn & 89.00 & 98.50 & 8.50 & 3.80 & 2.20 & 84.00 & 1.50 \\
\hline SBM & 92.20 & 93.90 & 44.00 & 0.80 & 7.00 & 42.10 & 6.10 \\
\hline JCSM & 91.30 & 91.98 & 43.00 & 1.80 & 7.00 & 40.18 & 8.02 \\
\hline Wheat bran & 90.00 & 94.10 & 11.00 & 3.00 & 11.00 & 69.10 & 5.90 \\
\hline Molasses & 22.00 & 85.80 & 0.30 & 0.14 & 0.41 & 84.95 & 14.20 \\
\hline
\end{tabular}

*Jatropha curcas seed meal, JCSM; Soybean meal, SBM.

DM, dry matter; OM, organic matter; CP, crude protein; EE, ether extract; CF, crude fiber; NFE, nitrogen-free extract.

Table 2: Feed ingredients and chemical analysis of the experimental diets.

\begin{tabular}{|c|c|c|c|}
\hline \multirow[b]{2}{*}{ Ingredients* } & \multicolumn{3}{|c|}{ The experimental dits ${ }^{1}$} \\
\hline & Control & $\begin{array}{c}\text { T1 } \\
50 \% \text { (JSM) }\end{array}$ & $\begin{array}{c}\text { T2 } \\
100 \% \\
\end{array}$ \\
\hline Alfalfa hay & 33 & 33 & 33 \\
\hline Yellow corn & 24 & 24 & 24 \\
\hline SBM & 12 & 6 & - \\
\hline Jatropha curcas seed meal (JCSM) & - & 6 & 12 \\
\hline Wheat bran & 25 & 25 & 25 \\
\hline Molasses & 3 & 3 & 3 \\
\hline Limestone & 1 & 1 & 1 \\
\hline $\mathrm{Ca}_{3}\left(\mathrm{PO}_{4}\right)_{2}$ & 0.5 & 0.5 & 0.5 \\
\hline Vit and Min mix ${ }^{\star \star}$ & 0.5 & 0.5 & 0.5 \\
\hline Salt & 0.5 & 0.5 & 0.5 \\
\hline Methionine & 0.25 & 0.25 & 0.25 \\
\hline Lysine & 0.25 & 0.25 & 0.25 \\
\hline Total & 100 & 100 & 100 \\
\hline \multicolumn{4}{|l|}{ Calculated analysis ${ }^{\star \star \star}:$} \\
\hline Crude protein & 15.87 & 15.98 & 15.63 \\
\hline Crude fiber & 13.64 & 13.79 & 13.75 \\
\hline Ether extract & 3.26 & 2.75 & 3.26 \\
\hline Digestible energy k cal/kg (DE)* & 2505 & 2499 & 2500 \\
\hline \multicolumn{4}{|c|}{ 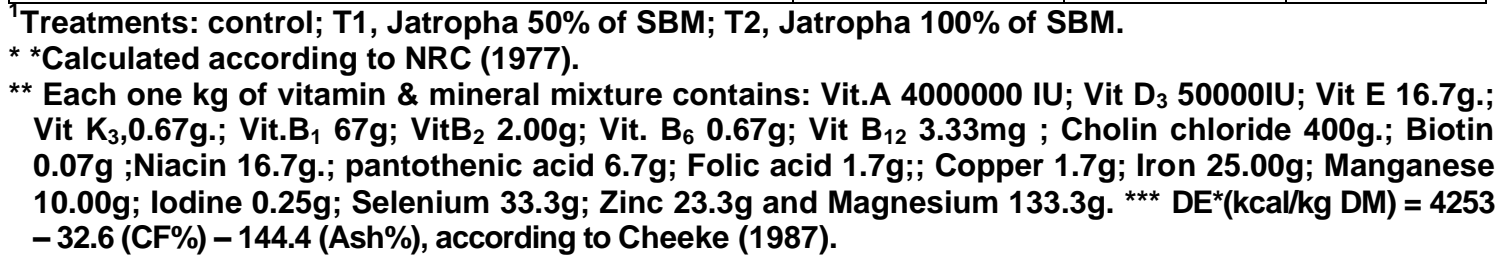 } \\
\hline
\end{tabular}




\section{Chemical analyses:}

Chemical analysis of the tested diets and feces were carried out according to AOAC (2000). Digestible energy (DE) of the experimental diets was calculated according by the equation described by Cheeke (1987).

\section{Statistical analysis:}

The data were statistically analyzed according to Snedecor and Cochran (1982) in one way analysis of variance design using SPSS (1997) program as the model:

$$
Y_{i j}=M+A_{i}+e_{i j}
$$

Where: $Y_{i j}=$ An observation, $M=$ Overall mean, $A_{i}=$ Effect of rations and $e_{i j}=$ Experimental error.

The significant differences between means were tested by using Duncan's multiple range test (Duncan, 1955).

\section{RESULTS AND DISCUSSION} Feed intake and feed conversion ratio:
Results of the feeding trial are shown in (Table 3). Daily TDN intake and energy intake of rabbits fed 50 and $100 \% \%$ JSM diets showed significantly $(P<0.05)$ higher values than those of the other diets. This may due to that the $50 \%$ JCSM diets was more palatable than control and T2 diets as suggested by Oladunjoye et al. (2014). These results are in agreement with Belewu et al. (2011) who reported that treated JCSM did not have any negative effect on feed intake, especially when JSM was taken from non-toxic variety. The result obtain in this study showed that there was no differences in the feed intake of rabbit that received diets containing JSM and those received the control diet. This contradict the report of Rakshit et al. (2008) who demonstrated that rat fed alkali and heat reduced appetite and low feed intake. This could be due to physiological adaptation resulting from differences in species. It can also mean that fermentation using fungi is better.

Table 3: Performance of growing NZW rabbits fed diets containing jatropha seed meal.

\begin{tabular}{|c|c|c|c|c|}
\hline \multirow[b]{2}{*}{ Weeks } & \multicolumn{3}{|c|}{ Treatments $^{1}$} & \multirow[b]{2}{*}{$\pm \mathrm{SE}$} \\
\hline & Control & $\begin{array}{c}\mathrm{T} 1 \\
50 \%\end{array}$ & $\begin{array}{c}\text { T2 } \\
100 \%\end{array}$ & \\
\hline No. of Animals & 16 & 16 & 16 & -- \\
\hline Duration of trail, days & 63 & 63 & 63 & -- \\
\hline Av. Initial weight, g & 685.42 & 677.28 & 689.21 & $2.15 \mathrm{NS}$ \\
\hline Av. Final weight, $\mathbf{g}$ & 2390.00 & 2414.07 & 2309.28 & $3.97 \mathrm{NS}$ \\
\hline Total gain, $\mathbf{g}$ & 1694.57 & 1736.78 & 1620.07 & $1.32 \mathrm{NS}$ \\
\hline Av. Daily gain, $\mathrm{g}$ & 26.89 & 27.56 & 25.71 & $1.17 \mathrm{NS}$ \\
\hline Av. DM intake, g (DM basis): & $5096.24^{b}$ & $5787.04^{a}$ & $5311.54^{b}$ & $3.01^{*}$ \\
\hline Av. TDN intake, $g$ & 3224 & 3538 & 3331 & 3.12 \\
\hline Av. DCP intake, $g$ & 636 & 745 & 676 & 2.18 \\
\hline \multicolumn{5}{|l|}{ Feed conversion ratio (FCR): } \\
\hline $\mathrm{Kg} \mathrm{DM} / \mathrm{kg}$ gain & $3.00^{b}$ & $3.33^{\mathrm{a}}$ & $3.28^{a}$ & $0.11^{*}$ \\
\hline $\mathrm{Kg}$ TDN/kg gain & 1.90 & 2.04 & 2.06 & $0.12 \mathrm{NS}$ \\
\hline Kg DCP/kg gain & 0.37 & 0.43 & 0.42 & $0.01 \mathrm{NS}$ \\
\hline Performance index (PI \%) & 79.67 & 72.49 & 70.40 & $2.67^{*}$ \\
\hline
\end{tabular}

Treatments: control; T1, Jatropha $50 \%$ of SBM; T2, Jatropha $100 \%$ of SBM.

$+a, b, c, d, e$ and $f$ Means with different superscripts on the same row are different at $(P<0.05)$. 
Change in body weight:

Results in Table (3) illustrated that, no significant difference regarding average body weight at any week of the experimental period, indicating that no adverse effect of any dietary treatment on the growth of the experimental rabbits. Final body weight was 2390, 2414 and $2309 \mathrm{~g}$ for control, 50 and $100 \% \mathrm{JSM}$ containing diets, respectively. This result agreed with those reported by Bamgbose et al. (1996) and Ojediran et al. (2014) who showed that rabbits that were fed diets in which JSCM replaced $50 \%$ soybean meal in their diets had higher final weight and average daily weight gain than those in control diet, while those fed $100 \%$ JSM had similar values with control group. The better performance observed in the rabbit on $50 \% \mathrm{JSM}$, it could have been due to better amino acid balance in this diet, which probably favor higher growth. Malviya et al. (2011) indicated that amino acid composition of Jatropha seed in excellent. Also the higher efficiency of feed utilization observed in the same group of rabbit could be due to the same reason.

The reduction in growth rate of rats in the heat-treated Jatropha group can't be attributed to lower feed intake but to reduced protein utilization whereas for rats on unheated Jatropha meal, the lower growth rate is attributed both to lower feed intake (21\%) and to lower protein utilization (63\%). Better performance of rats on the heat-treated Jatropha meal appears to be due to higher protein degradability and inactivation of trypsin inhibitors and lectins by heating.

\section{Body weight gain:}

The results in Table (3) represent that, the average live body weight (BW) and body weight gain (BWG) after 9 weeks showed no significant differences. The average daily gain followed the same pattern of total gain with average value of 26.89, 27.56 and 25.71g/d. Musa (2018) reported almost similar value of ADG for growing NZW rabbits when they were fed diets containing medicinal plant waste. This result agreed with those of Oladunjoye et al. (2014) who showed that rabbits fed diets in which JSCM replaced $50 \%$ soybean meal in their diets had higher final weight and average daily weight gain than those in control diet, while those fed $25 \% \mathrm{JCSM}$ and $75 \%$ JSCM had similar values with the control.

\section{Feed conversion ratio (FCR):}

Data in Table (3) showed feed conversion ratio ( $\mathrm{kg}$ feed $/ \mathrm{kg}$ gain) of growing rabbits as affected by the dietary treatments. It could be observed that rabbits fed control diet had significant $(P<0.05)$ difference in feed conversion ratio of 3.00 as $\mathrm{Kg} \mathrm{DM} / \mathrm{kg}$ gain, while those fed diets containing 50 and $100 \%$ JCSM had feed conversion ratio of 3.33 and 3.28 , respectively. On the other hand, no significant differences among all the experimental groups in rabbits performance expressed as $\mathrm{Kg} T \mathrm{TDN} / \mathrm{kg}$ gain or $\mathrm{Kg} \mathrm{DCP} / \mathrm{kg}$ gain.

This could have been due to the quality of feed intake along with rate. This result agreed with those reported by Oladunjoye et al. (2014) who reported that feed conversion efficiency of the rabbits fed $50 \%$ JCSM in replacement for soybean meal was higher $(P<0.05)$ than that of the group fed control.

\section{Performance index (PI\%):}

The performance index results of rabbits fed diets containing 50 and $100 \%$ of JSM showed significantly $(P<0.05)$ lower values than those fed the control diet (Table 4). On the other hand, diets which contained 50 or $100 \%$ of JCSM significantly $(P<0.05)$ performance index values were decreased by (9.01 and $11.64 \%)$ for.50 and $100 \%$ replacement of JCSM, respectively 
than those of the control diet. These results were in agreement with the finding of Cheeke and Patton (1979) and Zaki ElDin (1996).

\section{Mortality rate:}

There was no mortality observed neither of the rabbit fed control diet (SBM) nor fed JCSM diets. This in accordance with the report of Khalifa (2009) and Musa (2018) who mentioned that, no mortality was observed in rabbit fed medicinal plant and medicinal plant by- products.

\section{Digestion coefficients:}

Results given in Table (4) showed the apparent digestibility of nutrients as affected by different experimental treatments. The result revealed that higher digestibility of DM was obtained with the groups fed T1 or T2 diets being $66.85 \%$ and $66.5 \%$, respectively; while the lowest value achieved by the control group $(62.20 \%)$. This means that the replacement of JCSM in rabbit diets improved the DM digestibility by 6.1 and $7.7 \%$ compared with control diet. From statistical point of view, there is no significant difference between JCSM fed groups and control.

The digestion coefficient of OM tends to be higher in JCSM containing diets. The higher digestibility of OM was significantly $(P<0.05)$ obtained with groups fed T1 and T2 being 67.48 and $66.51 \%$ respectively, while the lowest value was achieved by group fed control diets $(61.26 \%)$. The result means that JCSM replaced in the rabbit diet at levels $50 \%$ or $100 \%$ improved the OM digestibility by $7.8 \%$ or $8.68 \%$ compared with control.

Data in Table (4) showed that the digestibility of CP recorded 80.56 and $86.98 \%$ for T1 and T2, respectively. The lowest value was achieved with the control (78.57\%). Also, the improvement in CP digestibility reached $3 \%$ in JCSM diets compared with control.

Table 4: Nutrient digestibility of the treated-diets by growing rabbits

\begin{tabular}{|c|c|c|c|c|}
\hline \multirow{2}{*}{ Item $^{*}$} & \multicolumn{3}{|c|}{ Treatments $^{1}$} \\
\cline { 2 - 4 } & Control & $\begin{array}{c}\text { T1 } \\
50 \%(J S M)\end{array}$ & $\begin{array}{c}\text { T2 } \\
100 \%(\text { (JSM) }\end{array}$ & \pm \\
\hline DM & 62.20 & 66.65 & 66.85 & 1.04 NS \\
\hline OM & $61.26^{\mathrm{b}}$ & $66.51^{\mathrm{a}}$ & $67.48^{\mathrm{a}}$ & $0.05^{\star}$ \\
\hline CP & 78.57 & 80.56 & 80.98 & $1.02 \mathrm{NS}$ \\
\hline CF & 53.00 & 56.53 & 57.61 & $1.12 \mathrm{NS}$ \\
\hline EE & 73.71 & 73.01 & 68.70 & $1.13 \mathrm{NS}$ \\
\hline NFE & 69.05 & 64.92 & 66.00 & $1.03 \mathrm{NS}$ \\
\hline TDN & 63.27 & 61.15 & 62.72 & $1.02 \mathrm{NS}$ \\
\hline DCP & 12.47 & 12.87 & 12.66 & $1.21 \mathrm{NS}$ \\
\hline
\end{tabular}

${ }^{1}$ Treatments: control; T1, Jatropha 50\%; T2, Jatropha $100 \%$.

$a, b, c^{\star *}$, Means having different superscript within each row are significant. NS, not significant.

*DM, dry matter; OM, organic matter; CP, crude protein; CF, crude fiber; EE, ether extract; NFE, nitrogen-free extract; TDN, total digestible nutrients; DCP, digestible crude protein. 
The digestibility of CF was improved by JCSM-fed groups compared with control. The improvement reached 6.2 and $8 \%$ in $\mathrm{T} 1$ and $\mathrm{T} 2$ diets, respectively. The groups fed T1 and T2 gave the highest CF digestibility compared to control group (53.00\%). Values of EE and NFE were not significant. It may be observed that the higher digestibility was relative due to lower feed intake lead to an increase in digestibility of almost nutrients. Baraghit et al. (1995) reported that digesta flow rate is negatively correlated with feed intake, which allow the nutrients to be available to the digestive enzymes for longer time. Makkar et al. (2009) reported that apparent protein digestibility values ranged between $80 \%$ and $92 \%$ for carp fed plant protein (detoxified Jatropha kernel meal and soybean meal) - based diets. Digestibility is a key factor in the evaluation of the quality of a diet and in particular in the determination of its potential for the synthesis of new tissues. Detoxified JPI and SPI, in combination with fish meal protein, showed excellent dry matter, crude protein, lipid and energy digestibility's indicating excellent utilization of feed ingredients.

\section{Nutritive values:}

The nutritive value of the experimental dietss expressed as TDN, DCP are presented in (Table 4). The results indicated that rabbits group fed diets T1 and T2 did not significantly differ from control group regarding DCP and TDN. These results indicated that using JSM in replacement of SBM had no bad effect on feeding value, moreover JSM is rich in nutrients and similar to SBM and to oilseeds and legumes as reported by Lauren (2010) and Abitogen and Ashogbone (2010).

\section{Nitrogen Balance:}

Data in Table (5) indicated that rabbits fed T1 diet containing 50 JCSM showed significantly $(P<0.05)$ higher $\mathrm{NI}$ than those fed control. Nitrogen excreted in urine (UN) was higher $(P<0.05)$ with rabbit fed 50 and $100 \%$ JSM groups than the control group, indicated that replacing JCSM with SBM decreased biological value (BV) leading to a decline in protein retention. On the other hand nitrogen excreted in feces (FN) was almost equal being $0.51,0.48$ and $0.49 \mathrm{~g} / \mathrm{d}$ for rabbits fed diets containing 50 and $100 \%$ JSM and control diets, respectively. These data are in complete agreement with the digestibility of CP (Table 3), leading to an increase in protein utilization.

Table 5: Nitrogen balance of growing rabbits as affected by dietary treatments

\begin{tabular}{|l|c|c|c|c|}
\hline \multirow{2}{*}{\multicolumn{1}{|c|}{ Item $^{*}$}} & \multicolumn{3}{|c|}{ Treatments $^{1}$} & \multirow{2}{*}{ 士SE } \\
\cline { 2 - 5 } & Control & $\begin{array}{c}\text { T1 } \\
50 \%(\text { JSM) }\end{array}$ & $\begin{array}{c}\text { T2 } \\
100 \%(J S M)\end{array}$ & \\
\hline Nitrogen intake, (g/d) & $2.39^{\mathrm{b}}$ & $2.63^{\mathrm{a}}$ & $2.53^{\mathrm{b}}$ & $0.05^{\star}$ \\
\hline Fecal nitrogen, (g/d) & 0.49 & 0.51 & 0.48 & $0.01 \mathrm{NS}$ \\
\hline Urinary N, (g/d) & $0.62^{\mathrm{b}}$ & $1.08^{\mathrm{a}}$ & $1.23^{\mathrm{a}}$ & $0.01^{\star}$ \\
\hline Nitrogen balance, (g/d) & $1.28^{\mathrm{a}}$ & $1.03^{\mathrm{ab}}$ & $0.82^{\mathrm{b}}$ & $0.05^{\star}$ \\
\hline Nitrogen digestibility, (g/d) & 1.91 & 2.12 & 2.05 & $0.01 \mathrm{NS}$ \\
\hline Nitrogen digestibility, (\%) & 79.30 & 80.60 & 81.05 & $2.15 \mathrm{NS}$ \\
\hline Biological value (NB/(NI-FN), (\%) & $67.21^{\mathrm{a}}$ & $48.49^{\mathrm{b}}$ & $40.16^{\mathrm{b}}$ & $0.01^{*}$ \\
\hline
\end{tabular}

${ }^{1}$ Treatments: control; T1, Jatropha 50\%; T2, Jatropha $100 \%$

a,b,c, Means having different superscript within each row are significant.NS, not significant 
It was noticed that NB in control, T1 and T2 were 1.28, 1.03 and 0.82 , respectively; T1 was close to the control diet but T2 was less than control. Biological value (B.V) of JSM diet was less than control diet. This may be attributed to that JSM has some decrease in essential amino acid as reported by Hamoda (2010) who found that the lower concentration was observed for sulfur containing amino acid; cystine (0.44) and methonine $(0.33)$ in addition to tyrosine (2.59 gm/100gm protein) comparing with SBM. Also this content was slightly lower than that of SBM protein reported in FAO (1990). Wang et al. (2011) indicated that the protein content of Jatropha curcas seed cake protein isolates (JPI) was $84.4 \%$ similar to the $89 \%$ reported by Saetae and Suntornsuk (2011). There was a decrease in methionine, lysine and leucine contents, but an increase in the arginine content was noted in the diets containing increasing amounts of jatropha protein isolate (JPI). Previous reports also showed that the JPI had the highest arginine content, followed by aromatic (phenylalanine + tyrosine) and nonpolar AA (leucine, isoleucine, alanine, glycine, valine, and proline) (Makkar et al., 2008; Peralta-Flores et al., 2012). Compared with the FAO (1990), the protein fractions of $J$. curcas provide all EAA in sufficient amounts with the exception of lysine and tryptophan (Peralta-Flores et al., 2012). Yinuo Zhaoa et al. (2018) indicated that in terms of the limiting AA, the lysine contents of the JPI 40 and JPI 60 groups were lower than the FAO recommended value of $5.80 \%$ of CP (FAO, 1990). A low content of lysine and a high content of arginine in JPI-fed rats may cause an imbalance in the proportion of these AA. Moreover, lysine and arginine exert antagonistic function in digestion, absorption and renal reabsorption; therefore, the $A A$ composition may lead to a decline in the utilization of this protein in the diet of rats.

\section{Economic Impact:}

Accordingly, feed cost per kg gain and economic impact was better with diets containing 50 and $100 \mathrm{JCSM}$ meals than those fed control diet Table 8. It was noticed that the cheaper in feed cost $/ \mathrm{kg}$ gain 26.20 and 22.25 L.E. for diets containing 50 and $100 \%$ JCSM, while diet containing control was the highest of the other groups (26.50 L.E.). Total revenue was 57.61, 59.15 and 55.08 PT for the same respective groups. This can be attributed to lower cost of JCSM used in this study which came from biodiesel industry, therefore, it is cheaper than the one was processing for the commercial purpose of marketing. Economic impact of the different formulated diets and relative economic efficiency at the end of the experimental period indicated that all experimental diets had lower cost than the control group. Comparing to the control group (assuming 100\%). The best relative economic efficiency were reported with the group T2 being $126 \%$ followed by $\mathrm{T} 1$ being $108 \%$. In general, using JCSM to replace soybean meal at the two levels of tested feeds lead to better economic efficiency. These results agree with finding with Oladunjoye et al. (2014) mentioned that, feeding growing rabbits fermented (JSCM) by Aspergillus niger substituted for either 25,50 or $75 \%$ soybean meal (wt/wt) in the control diet, feed cost increased with increase JSCM in the diets. Production cost was lower $(P<0.05)$ at $50 \%$ substitution level than in control diet but higher $(P<0.05)$ at $25 \%$ and $75 \%$. So, economic reason $50 \%$ should be replaced. 
Productive performance of growing new zealand rabbits fed jatropha

Table 6: Economic impact of growing rabbits as affected by feeding dietary treatments

\begin{tabular}{|c|c|c|c|}
\hline \multirow[b]{2}{*}{ Items } & \multicolumn{3}{|c|}{ Treatments $^{1}$} \\
\hline & Control & $\begin{array}{c}\mathrm{T1} \\
50 \% \text { (JSM) }\end{array}$ & $\begin{array}{c}\text { T2 } \\
100 \% \text { (JSM) }\end{array}$ \\
\hline Av. feed intake (kg/rabbit), a & 5.1 & 5.7 & 5.3 \\
\hline Price (LE)/ kg feed, $b^{2}$ & 5.20 & 4.7 & 4.2 \\
\hline Total feed cost, (LE; $\left.a^{*} b=c\right)$ & 26.50 & 26.20 & 22.25 \\
\hline Total weight gain, $\mathbf{k g}(\mathrm{d})$ & 1.69 & 1.74 & 1.62 \\
\hline Price L.E/kg live body weight, $\mathrm{e}^{2}$ & 34 & 34 & 34 \\
\hline Total revenue $(L E)\left(d^{*} e=f\right)$ & 57.61 & 59.15 & 55.08 \\
\hline Net revenue (LE) $(f-c=g)$ & 31.11 & 31.96 & 32.83 \\
\hline Economic impact $(\mathrm{g} / \mathrm{c})^{3}$ & 1.17 & 1.18 & 1.48 \\
\hline Relative economic impact ${ }^{4}$ & 100 & 108 & 126 \\
\hline
\end{tabular}

'Treatments: control; T1, Jatropha 50\%; T2, Jatropha 100\%

According to the price of different ingredients available in the market at the experimental time (2018)

${ }^{2}$ According to the local market price at the experimental period.

${ }^{3}$ Net revenue per unit cost.

${ }^{4}$ The economic impact relative to the control group.

In conclusion, from the previous results, jatropha seed meal can be used up to 50 or $100 \%$ instead of soybean meal in the growing New Zealand rabbit diets improved the digestibility, daily weight gain, feed and economic impact, without any adverse effects on growth performance.

\section{REFERENCES}

A.O.A.C. (2000). Association of Official Analytical Chemist's. Official methods of Analysis. $16^{\text {th }}$ Edition, Washington, D.C.

Abitogun, A.S. and A.O. Ashogbon (2010). Nutritional assessment and chemical composition of raw and defated Luffa cylindrical seed flour, Ethan-botanical leaflets. Ethnobotanical Leaflets. (3) 14:225.

Agboola, A.F. and A.A. Adenuga (2015). Performance and organ histopathology of growing Japanese quails (Coturnix coturnix japonica) fed heat treated Jatropha seed cake substituted for soybean meal. Trop. Anim. Prod. Invest. 18 (1): 1-8.

Bamgbose, A.M., S. Bogoro and S.O. Nwokoro (1996). Processing and utilization of soybean in ration of poultry in Nigeria: A Rev. Agr. Revolution., 17: 93-102.

Baraghit, G.A., B.M. Ahmed, A.M. Shehata and H.T. Taie (1995). Effect of clover intakes by sheep and goats on digestion kinetics. 5th Scientific Conf. Anim. Nutr. Ismailia, Egypt.

Belewu, M.A. (2008). Replacement of Fungus treated Jatropha curcas seed meal for Soybean meal in the diet of rat. Green Farming J.,2(3):154-7.

Belewu, M.A., K.Y. Belewu and I.A. Lawal (2011). Cocktail of fungi blend on Jatropha curcas kernel cake: effect on feed intake and blood parameters of goat. Libyan Agriculture Research 
Center Journal International, 2, 138143.

Cheeke, P. R. (1987). Rabbit Feeding and Nutrition. Academic Press.

Cheeke, P.R. and N.M. Patton (1979). The effect of fibre sources on growth and enteritis in rabbits an update. J. Appl. Rabbit. Res., 2: 3 - 5.

Chivandi, E., K.H. Erlwanger, S.M. Makuza, J.S. Read and J.P. Mtimun. (2006). Effects of dietary Jatropha curcas meal on percent packed cell volume serum glucose, cholesterol and triglyceride concentration and alpha-amylase activity of weaned fattening Pigs. Res. J. Anim. Vet. Sci., 1 (1): 18-24.

Duncan, D.B. (1955). Multiple range and multiple F-test. Biometrics,11: 1-42.

El-Kerdawy, M.A. (1997). Olive pulp as a new energy source for growing rabbits. Egyptian J. Rabbit Sci., 7 (1): 1 - 12.

FAO, (1990). Rabbit Production. The 12th Session of the FAO.

Hamoda, Shirin. (2010). chemical and techonological studies on jatropha seeds for the use in food industry. PhD . Thesis, Animal Production Dept., Faculty of Agriculture, Minufia University.

Khalifa, A.S. (2009). The use of medical herbs in animal nutrition. MSc. Thsis, Faculty of Agric., Minufiya Uni., Egypt.

Lauren, J.G., R. Shrestha, M.A. Sattar and R.L. Yadau (2010). Legumes and diversification of rice. Wheat cropping system. pp.67-102.

Makkar, H.P.S., G. Francis and K. Becker (2008). Protein concentrate from Jatropha curcas screw-pressed seed cake and toxic and anti-nutritional factors in protein concentrate. J. Sci Food Agric, 2008; 88:1542-1548.

Makkar, H.P.S. and K. Becker. (1999). Plant toxins and detoxification methods to improve feed quality of tropical seeds. Asian Aust. J. Anim. Sci. 2:467-480
Makkar, H. P., S. Kumar, V. Shkelqim, K. S. Kratzeisen, M. Tipraqsa, P. Müller, J. Berger, T. Amselgruber; K. Becker (2009) Sustainable land development and ecosystem conservation through enhancing economic viability of the Jatropha curcas based biodiesel production chain using a bio-refinery concept. In ERSEC (2009): Sustainable Land Use and Ecosystem Conservation, International conference Proceeding, Beijing.

Malviya, S.N., R. Malakar, M. Yadav, A. Mishra and A. Tiwari (2011). Estimation and characterization of protein present in seed extractof Jatropha curcas. Advance Research in Pharmaceuticals and Biology. 2011; 1 (1): 35-38.

MSEA (2008). Ministry of State for Environmental Affairs. Egyptian Environmental Affairs Agency September. Feasibility study on growing Jatropha utilizing treated waste water in Luxor.

Mousa, A. M. Z. (2018). Utilization of some Medicinal plants wastes in animal nutrition PhD. Thesis, Animal Production Dept., Faculty of Agriculture Menoufia University.

Nabil, A.E. Azzaz, Neveen A. El-Nisr, Eman E. Elsharkawy and Eman A. Elmotleb (2011). Chemical and pathological evaluation of jatropha curcas seed meal toxicity with or without heat and chemical treatment. Australian Journal of Basic and Applied Sciences, 5(12): 49-59,

North, M. O. (1981). Commercial Chicken Production. Manual 2nd Edition. ANI publishing Company ING, USA.

NRC, (1977). National Research Council. Nutrient Requirements of Rabbits. Washington, DC., U. S.A.

Ojediran, T.K., Y.A. Adisa, S.A., Yusuf and I. A. Emiola (2014). Nutritional evaluation of processed Jatropha curcas kernel meal: Effect on growth 
performance of broiler chicks. J Anim. Sci. Adv.; 4(11): 1110-1121.

Oladunjoye, O., O. O., Ojebiyi, T. Ojediran, A. B. Adeniyi and S.A. Shonibare (2014). Evaluation of Jatropha (Jatropha curcas L.) Seed Cake Meal as Feed for Rabbit International $\mathbf{J}$. of Agri. Innovations and Research 2, (6), ISSN (Online) 1473-2319.

Peralta-

Flores, S. Gallegos-

Tintorea, J. Solorza-Feria, G. DavilaOrtiz, L. Chel-Guerrero

and A. Martínez (2012). Biochemical evaluation of protein fractions from physic nut (Jatropha curcas L.) Grasas Aceites, 63 (3). 253-259.

Rakshit, K.D., J. Darukeshwara, K. Rathina Raj, K. Narasimhamurthy, P. Saibaba and S. Bhagya (2008). Toxicity studies of detoxified Jatropha meal (Jatropha curcas) in rats. Food and Chemical Toxicology. 46 (12): 3621-3625.

Saetae, D. and W., Suntornsuk (2011). Toxic compound, anti-nutritional factors and functional properties of protein isolated from detoxified Jatropha curcas seed cake Int J. Mol. Sci, 12, 66-77.

Snedecor, G.W. and W.G. Cochran (1982). Statistical Methods .6th Edition. Iowa State University Press. Ames. U.S.A.

SPSS, (1997). (Statistical Package for Social Science) program version 13:0.

Wang, Y.B., Y.N. Zhao, H.F. Wang and J.X. Liu (2011). Determination of conditions for extraction of protein isolate from Jatropha curcas seed cake. Chin J Anim Sci, 47 (21): 53-55.

Yinuo Zhao, Yubao Wang, Haifeng Wang, Yueming Wu, Harinder P. Makkar and Jianxin Liua (2018). Nutritional value of detoxified Jatropha curcas seed cake protein isolates using rats as an animal model. Anim. Nutr. 4 (4), December 2018, Pages 429-434.

Zaki El-Din, M. (1996). Effects of source and level of dietary fibre on growth, nutrient digestibility and carcass characteristics of rabbits. Egypt. Poultry Sci. J., 16 (11): 221 - 238. 
الأداء الانتاجى للأرانب النيوزلندى البيضاء النامية المغذاة على كسب بذرة الجاتروفا

$$
\begin{aligned}
& \text { كمال محد عبد الرحمن (1)، حمدي توفيق طايع(1)، جمال أحمد براغيت(1)، }
\end{aligned}
$$

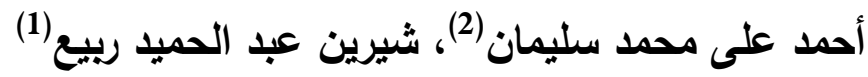

$$
\begin{aligned}
& \text { (1) قسم الإنتاج الحيواني - كلية الزراعة - جامعة المنوفية - مصر . }
\end{aligned}
$$

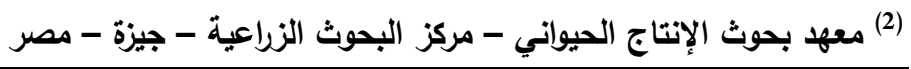

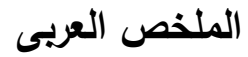

تم تقسيم 48 من الأرانب النيوزيلندي الأبيض عمر 4 أسابيع ومتوسط وزن حي 670+28 جم قسمت عشوائيا على ثلاثة مجموعات تجريبية متساوية (16 أرنب في كل مجموعة)، وزعت المجموعات التجريبية على ثلاثة علائق مختلفة

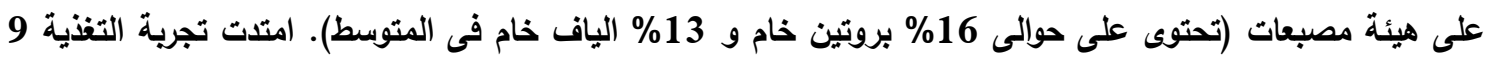

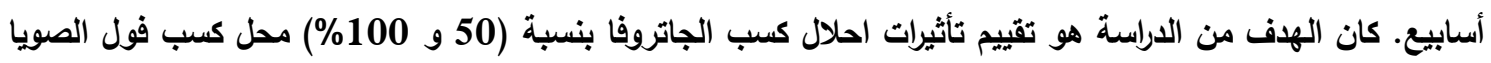
كمصدر للبروتين النباتى فى عليقة المقارنة على القيم الهضمية و معدل النمو و معامل تحويل الغذاء التهات والكفاءة الاقتصادية. وقد أثنارت النتائج المتحصل عليها إلى أنة لا توجد فروق معنوية فى كمية الغذاء المأكول بالنسبة للأرانب التى غذيت

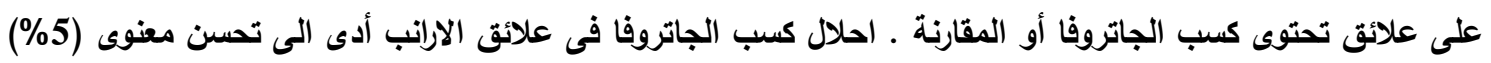
فى قيم المعاملات الهضمية للمادة الجافة للارانب التى غذيت على علائق تحتوى على على 50 على 50 و 100 1.

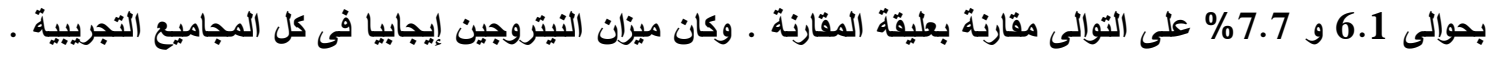

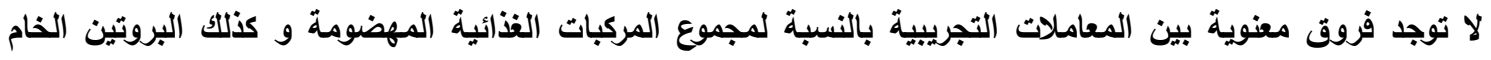

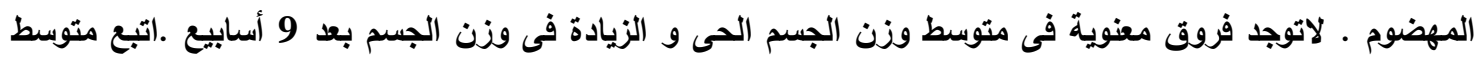

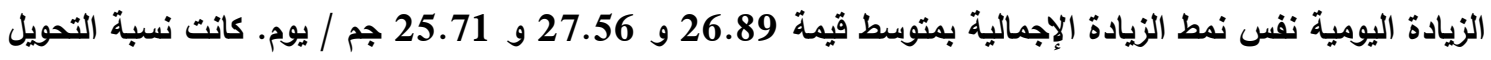

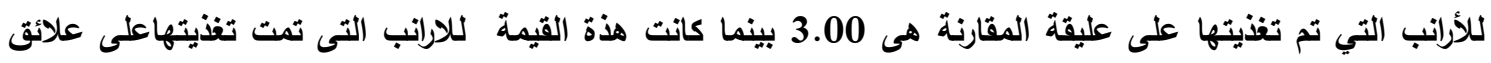

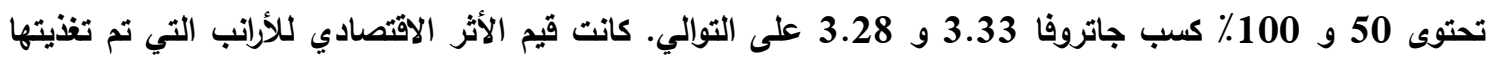

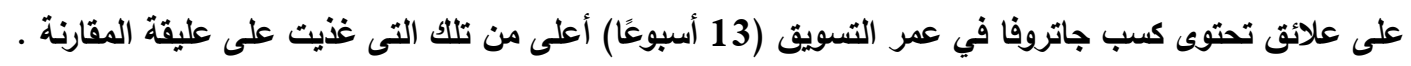

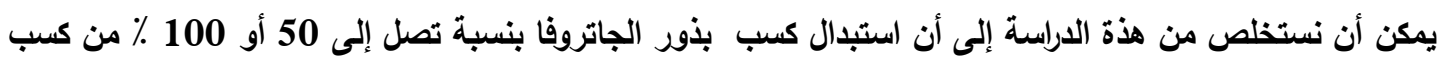

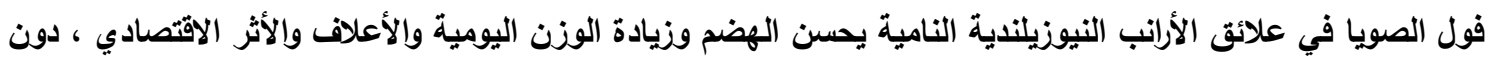
أي آثار سلبية على الأداء الإتتاجي للارانب.

أسماء السادة المحكمون:

1- أ.د. جمال على الصياد كلية الزئية المراعة - جامعة بنها

2- أ.د. بركات محمد أحمد كلية الزراعة - جامعة المنوفية 
Productive performance of growing new zealand rabbits fed jatropha 